\title{
How do field margins contribute to the functional connectivity of insect-pollinated plants?
}

\author{
Clémence Guiller $\cdot$ Laurence Affre • \\ Cécile Hélène Albert • Thierry Tatoni • \\ Estelle Dumas
}

Received: 26 April 2015/ Accepted: 14 March 2016

\begin{abstract}
Context Habitat fragmentation generates a loss of functional connectivity detrimental to the persistence of biodiversity. The French agricultural intensification initiated in the 1950s has caused a decline in field margins.

Objectives As field margins may facilitate species dispersal while providing socio-economic benefits, it is of interest to assess their contribution to the functional connectivity of insect-pollinated plants in agro-ecosystems. This will help develop appropriate management strategies mitigating fragmentation.

Methods We addressed this issue by studying the links between landscape structure and the patterns of abundance and pollen dispersal (using fluorescent dye particles) for two contrasted insect-pollinated plants occurring in field margins (Crepis sancta and Euphorbia serrata). We investigated the influence of field margins quality and of the surrounding matrix on
\end{abstract}

Electronic supplementary material The online version of this article (doi:10.1007/s10980-016-0359-9) contains supplementary material, which is available to authorized users.

C. Guiller $(\bowtie) \cdot$ L. Affre · C. H. Albert .

T. Tatoni · E. Dumas

Institut Méditerranéen de Biodiversité et d'Ecologie Marine et Continentale (IMBE), Aix Marseille Université, CNRS, IRD, Avignon Université, Faculté des Sciences et Techniques St-Jérôme, Avenue Escadrille Normandie Niémen, Case 421, 13397 Marseille Cedex 20, France e-mail: clemence.guiller@imbe.fr pollen dispersal and compared the relevance of the least-cost algorithm with a straight-line approach to depict pollinators' movements.

Results The influence of landscape structure on plant abundance is species and scale-specific. Pollen dispersal decreases with distance from the source. For $E$. serrata, it was preferentially dispersed via field margins, confirming the relevance of the least-cost algorithm, while $C$. sancta dispersal followed a straight-line.

Conclusions Euphorbia serrata, which grows strictly on field margins with a greater dispersal ability and a more diversified pollinator guild than C. sancta, is less affected by land-use changes. Our study demonstrates the contrasting contributions of field margins to pollen dispersal as they may act as functional corridors favouring pollinators' movement depending on the species of interest.

Keywords Landscape connectivity - Fluorescent dye particles - Gene flow · Mediterranean agro-ecosystems $\cdot$ Least-cost algorithm

\section{Introduction}

Habitat destruction and fragmentation undermine a species capacity to withstand environmental, demographic, and genetic stochasticity due to reduced population sizes and constraints on individual movement that 
can lead to reduced gene flow and ultimately local extinction (Young et al. 1996; Leimu et al. 2006; Honnay and Jacquemyn 2007) but fragmentation still leads to controversial results (Fahrig 2003; Ethier and Fahrig 2011). In this context there is a need for further investigations on species response at the landscape-scale. Landscape connectivity - the degree to which the landscape facilitates or impedes movement of organisms among resource patches' (Taylor et al. 1993) — is a useful concept to aid the formulation of effective management strategies ensuring the persistence of spatially-structured species (Calabrese and Fagan 2004). Particularly relevant is the functional dimension of landscape connectivity that accounts for organisms' perception of the landscape (Tischendorf and Fahrig 2000).

Classically, assessing functional connectivity relies on the estimation of resistance values that index the ease of movement through each landscape feature (Ferreras 2001). These resistance values can be expert-based or more rarely calibrated via an empirical approach (Zeller et al. 2012). Landscape resistance together with the leastcost algorithm can be used to quantify inter-patch effective distances (Adriaensen et al. 2003). Contemporary studies largely emphasise the superiority of the least-cost algorithm over a straight-line distance to predict the influence of landscape structure on species dispersal (Chardon et al. 2003; Sutcliffe et al. 2003; Stevenson et al. 2013; Etherington et al. 2014). In plant species, gene flow is a key process mediated by both seed and pollen dispersal. Petit et al. (2005) have showed however that at landscape level, pollen dispersal is the major driver for gene flow and may thus be a key element for investigating the functional connectivity of insectpollinated plant species (e.g. Van Geert et al. 2010). Although knowledge of pollen dispersal would be essential to the design and management of networks such as 'green-veining' (Grashof-Bokdam and Langevelde 2005), it remains an understudied aspect of the functional connectivity of common plant species. Functional connectivity has indeed been much more explored for animals than for plants especially by means of resistance modelling (but see empirical studies by Tewksbury et al. 2002; Townsend and Levey 2005).

Landscape structure management is of central interest for agro-ecosystems. Indeed, the emergence of post-1950s French intensive agricultural policies has resulted in crop homogenisation and a wide loss of natural and semi-natural habitats like agro-ecological infrastructures (e.g. hedgerows; Le Roux et al. 2008) leading to a strong decline in farmland biodiversity (Benton et al. 2003; Tscharntke et al. 2005). Among agro-ecological infrastructures, field margins are particularly interesting regarding functional connectivity as they may act either as shelters or as links for dynamic processes (Marshall and Moonen 2002) and thus facilitate pollen dispersal (Van Geert et al. 2010), a major agro-ecosystems service (Klein et al. 2007). Field margins represent here the uncultivated strips of shrubby or herbaceous vegetation located at the interface between a field and another landscape feature (a field, a road or a path). In the Luberon Regional Natural Park (south-eastern France), where landmanagers aim to reconcile a sustainable economic development with biodiversity conservation, the future of field margins and their typical plant associations remains uncertain due to increasing pressures from agricultural intensification and urban sprawl (Meyer-Vale 2012).

In this study, we combine an experimental protocol using fluorescent dye particles as pollen analogues and a modelling approach in order to disentangle the contributions of field margins and the matrix on the functional connectivity of common insect-pollinated plant species. From a preliminary analysis on species assemblages and functional traits we selected two representative species of typical functional groups encountered in field margins within the Luberon Regional Natural Park, Crepis sancta and Euphorbia serrata. We address the four following questions: (i) To what extent does landscape structure modulate plant species abundance within field margins?, (ii) Does insect-mediated pollen dispersal preferentially occur via field margins?, (iii) Does field margins quality and matrix heterogeneity influence pollinator movements? and (iv) What are the challenges in modelling functional connectivity for insect-pollinated plants? We finally discuss the implications of our findings on the abundance and dispersal patterns of common plant species for land-managers in agro-ecosystems.

\section{Methods}

Study site and species

Study site

The study site is located in the southern area of the Luberon Regional Natural Park $\left(5^{\circ} 30^{\prime} 35.68^{\prime \prime} E\right.$, 
$43^{\circ} 44^{\prime} 1.853^{\prime \prime} \mathrm{N}$; Fig. 1) at the interface between the intensive agricultural systems of the Durance valley and the traditional farming systems of the Luberon massif (Guende and Olivier 1993). The study site extends over $24 \mathrm{~km}^{2}$ including urban, natural and agricultural areas.

The landscape is dominated by viticulture (48\%) and woodlands, which are meso-Mediterranean formations under the influence of the Mediterranean climate (19\%), while cereal fields (12.5\%), buildings (7.7 \%) and olive groves $(2 \%)$ occupy a smaller proportion. Three small villages and one medium-sized dynamic city, Pertuis (population growth rate of $0.5 \%$ per year during the period 2007-2012, equal to the rate for the metropolitan France; Biau and Chauvot 2014) also surround the study site. Within agricultural areas, we identified two main types of practices: $30 \%$ of unploughed fields (perennial fields such as vineyards and olive groves in which no ploughing occurred before and during our field surveys thus enabling the development of C. sancta) and $70 \%$ of ploughed fields (ploughing occurred before our field surveys in some perennial fields and in all cereal fields thus preventing the development of non-cultivated plants within them). From the observation of ortho-photos (cell size: $0.5 \mathrm{~m}$, Coordinate system: Lambert 1993), we created two shape files in ArcGIS 10.2. (Esri 2013), one delineating land-use polygons and one depicting field margins as polylines. Then, during our field surveys in March 2014, we (i) informed each polygon according to its effective land-use type (buildings, fallow lands, pastures, paths, ploughed fields, roads, unploughed fields, water or woody habitats), (ii) manually geo-rectified the drawing of the field margins network and (iii) specified the typology of the field margin (a 'field/field', a 'field/ road' or a 'field/path' field margin). The field margins network extends over $293 \mathrm{~km}$, accounting for 2545 field margins.

\section{Study species}

Our selection of study species was based on several criteria. First, we used the SILENE database (http:// flore.silene.eu/) to identify the most frequent plant species at the study site, i.e. occurring in at least 90 relevés. Second, our choice was oriented towards

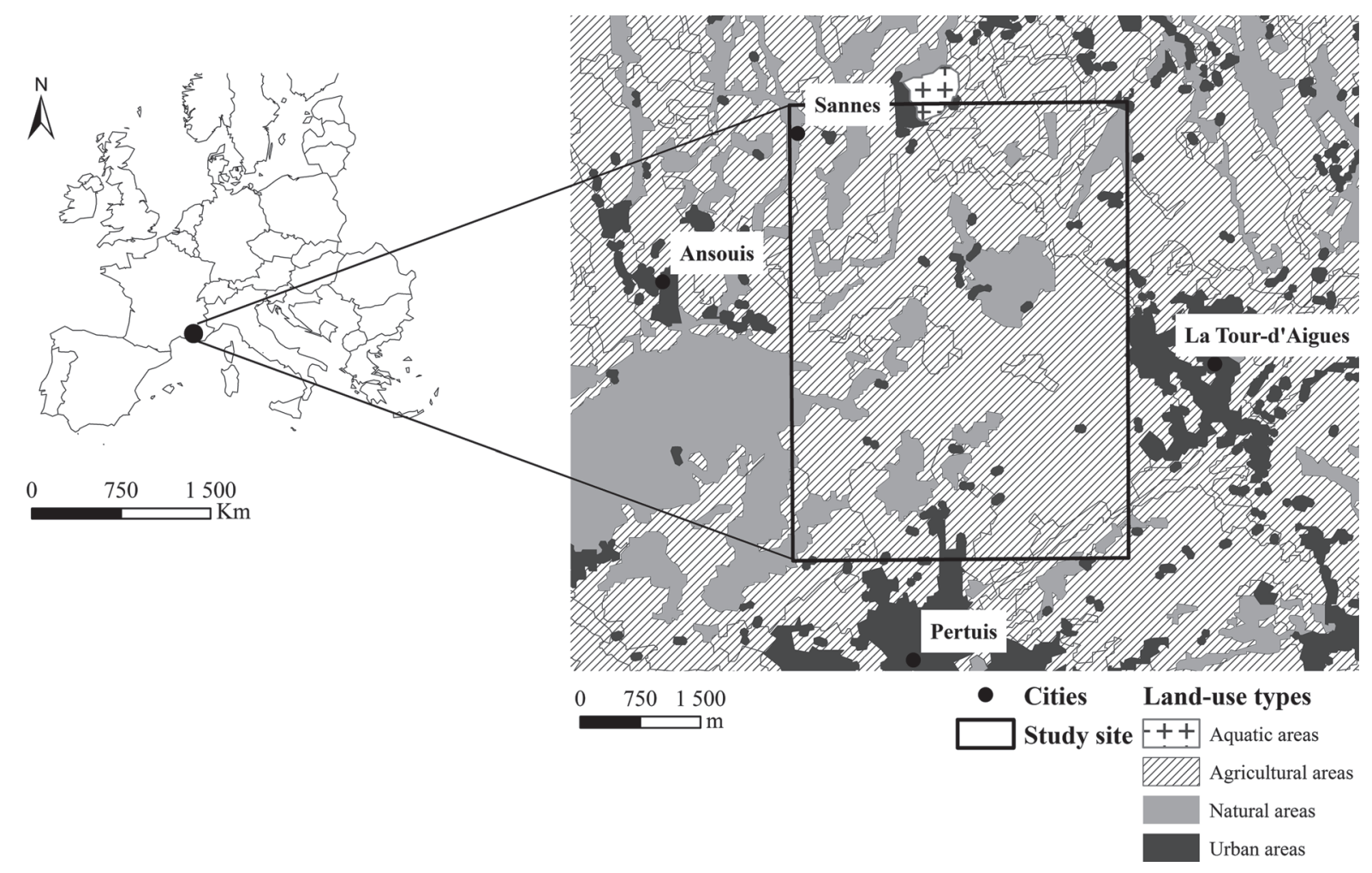

Fig. 1 Location of the study site (south-eastern France) and main land-use types 
entomophilous plant species with spring flowering. Third, among the remaining species we identified the main contrasted functional strategies based on lifehistory traits, e.g. biological type, seed dispersal and major orders of pollinators. Finally, we checked for species representativeness in field margins. Two plant species fulfilled all of the above conditions: $C$. sancta L. Bornm (Asteraceae) and E. serrata L. (Euphorbiaceae). Crepis sancta is an annual herb with leafless flowering stems. It is insect-pollinated mainly by Apoidea such as Panurgus dentipes and Apis mellifera (C. Guiller, pers. obs.). It is a seed heteromorphic species with seed achene dispersed by anemochory and barochory (Imbert 2001). Conversely, E. serrata is a perennial herb with a thickened root, characterised by ovate-lanceolate leaves with finely toothed margins. Inflorescences are held in umbels containing nectar glands. It is mainly pollinated by Hymenoptera, e.g. Athalia rosae, Macrophya montana and Tenthredo atra, and Diptera, e.g. Graphomya maculata and Sarcophaga carnaria (C. Guiller, pers. obs.). Seeds disperse over short distances by projection coupled with myrmecochory (Baiges and Blanché 1991). According to the literature, both species occupy similar habitats such as disturbed sites, roadsides or grassy margins of vineyards (see Saatkamp et al. 2007), although we also recorded C. sancta in some unploughed fields. We can still consider from our field observations that field margins are the principal habitat for both species.

\section{Species response to landscape structure}

We assessed the influence of landscape structure, and particularly field margin configuration, on the distribution and abundance of $C$. sancta and E. serrata. For each species, we allocated a degree of abundance to each of the 2545 geolocated field margins ( 0 : absent; 1 : rare; 2: regular; 3: abundant). We repeated the analyses at two spatial scales (windows of 250 and $500 \mathrm{~m}$ radius centred on the sampled field margins) in order to identify relevant spatial scales for these biological patterns. Furthermore, to avoid overlaps between windows, we sampled a subset of field margins among the 2545 recorded ones as follows: (i) one field margin was randomly selected, (ii) a buffer of 250/500 m was applied around the selected field margin, (iii) the next central field margin was randomly selected beyond this buffer, and finally steps (ii) and (iii) were repeated until the study site was completely covered by buffers around selected field margins. It represented respectively 30 (250 m scale) and $15(500 \mathrm{~m})$ windows. To depict the availability and quality of suitable habitats, we initially selected seven landscape indices reflecting both landscape composition (i.e. proportion of unploughed fields, proportion of ploughed fields, proportion of pastures and fallow lands) and configuration (i.e. landscape heterogeneity, interspersion-juxtaposition index, number of connections per field border, density of field margins in $\mathrm{m} / \mathrm{ha}$ ). Landscape heterogeneity (Burel and Baudry 1999) is measured via the Shannon formula. The interspersion-juxtaposition index (McGarigal et al. 2012) evaluates patch adjacencies; the higher this index is the more interspersed patch types are. Furthermore, the number of connections per field margin ' $i$ ' is defined as the total number of field margins ' $j$ ' that intersect with ' $i$ '. These indices were estimated through the Chloe software (Boussard and Baudry 2014), with the exception of the interspersionjuxtaposition index calculated with FRAGSTAT (McGarigal et al. 2012) and the number of connections via ArcGIS. Pairwise correlations on these seven landscape indices at each spatial scale ('cor.test', Ade4 R-package; see Electronic supplementary material) allowed selecting four uncorrelated indices, common to both spatial scales, i.e. the landscape heterogeneity, the density of field margins, the proportion of unploughed fields and the proportion of pastures and fallow lands). We performed generalised linear models (' $\mathrm{glm}$ ', Ade4 R-package) with a probit link to relate landscape indices with the degree of abundance of each species (ordinal variable converted into proportional data ranging from 0 - 'absent' to 1 'abundant'). To identify the best model, we operated a removal procedure based on a full model including the four explanatory variables, until all the combinations of variables had been tested. Following Burnham et al. (2011), we explored the support from empirical data for each model using the corrected Akaike information criterion (AICc), Akaike weights $\left(\omega_{\mathrm{i}}\right)$ computed by AICcmodavg R-package and the evidence ratio, i.e. ratio of Akaike weights of model $i$ and $j$ (evidence ratio $\left.=\omega_{\mathrm{i}} / \omega_{\mathrm{j}}\right)$.

\section{Pollen dispersal via fluorescent dye particles}

In order to understand the link between landscape structure and pollen dispersal, and to check whether 
pollinators preferentially follow field margins to move between floral resources, we used an experimental tool, i.e. the fluorescent dye particles analogues to pollen flow (Van Geert et al. 2010). Our experimental protocol involved four steps reiterated for both species. First, we identified two 1000 m radius nonoverlapping experimental areas centred on a 'source' field margin per study species, defined as a field margin with the highest plant abundance (C. sancta or E. serrata). We ensured that the two experimental areas were representative of the study site (similar in terms of proportions of land-use). Second, fluorescent dye particles were installed at the optimum of the flowering period (March-April), on a single day without any wind or precipitation (between 8:00 and 10:00 a.m.). In each experimental area, we identified a $5 \mathrm{~m}$ segment on the source field margin within which we applied pink fluorescent particles (RADGLO $\mathrm{JST}^{\circledR}$ ) on five randomly-selected plants and five randomly-selected mature inflorescences per plant (thus 25 inflorescences). Third, $48 \mathrm{~h}$ later, we sampled inflorescences in field margins following a 'Step-bystep' protocol (Fig. 2), i.e. sampling from the source over classes of geometrical distances following the network of field margins $(5-10 ; 15-20 ; 35-40 ; 75-80$; 155-160; 315-320; 635-640; 1275-1280 m). We collected a maximum of five mature inflorescences per plant on five randomly selected plants (depending on availability), for each distance class. Samples were individually stored in airtight bags. We accounted a total of 72 sampling points for $C$. sancta and 96 for $E$. serrata, representing 773 and 1869 collected inflorescences respectively. Fourth, the occurrence of the fluorescent dye particles was observed under a UV lamp for each collected inflorescence.

\section{Measuring permeability from field observations}

Defining permeability values for each landscape feature (i.e. the fraction of organisms traversing a given landscape feature; Adriaensen et al. 2007) is a prerequisite to apply the least-cost algorithm. Following the recommendations of Zeller et al. (2012), we used our empirical data to calibrate permeability values proper to the pollinators guilds of $C$. sancta and E. serrata. We assessed the 'frequency that a given landscape feature (e.g. road, building, fallow land, field margin) is traversed by pollinators' to obtain a 'landscape permeability map'. We considered two

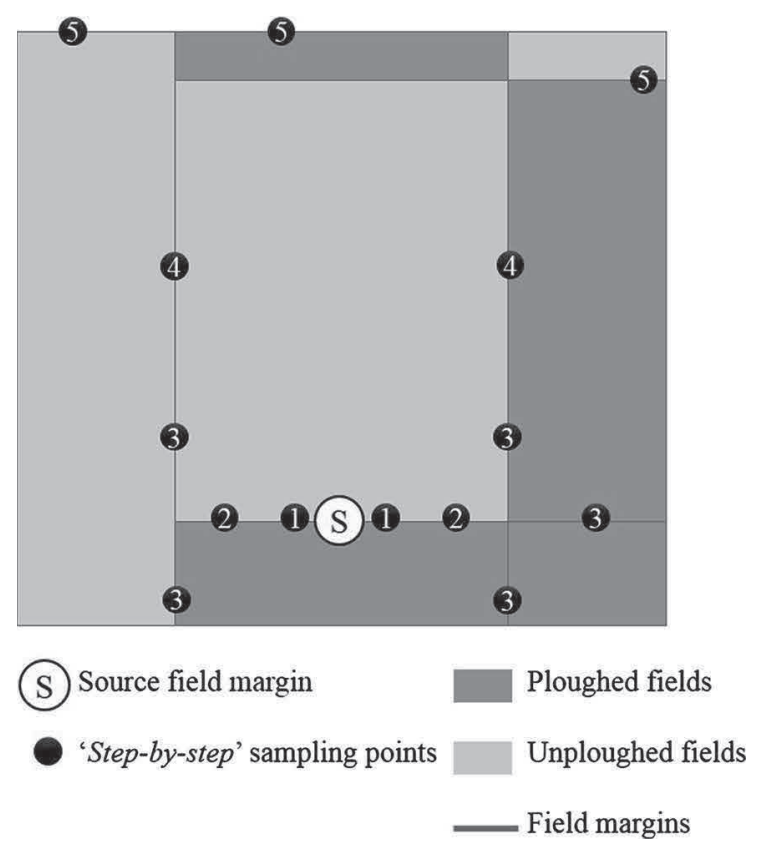

Fig. 2 Details of the 'Step-by-step' protocol at the scale of classes of geometrical distances: $1(5-10 \mathrm{~m}), 2(15-20 \mathrm{~m}), 3$ $(35-40 \mathrm{~m}), 4(75-80 \mathrm{~m})$ and $5(155-160 \mathrm{~m})$ up to $1275-1280 \mathrm{~m}$

types of potential paths to help assigning the permeability of each landscape feature: (i) pollinators follow field margins (Fig. 3a) or (ii) pollinators move in a straight-line throughout the matrix (Fig. 3b). We defined a potential path as a series of displacements from the source (i.e. centre of the field margin receiving fluorescent dyes) to a destination point (i.e. 'Step-by-step' sampling points) via multiple landscape features. The permeability of the landscape feature ' $i$ ' is given by:

Permeability $=n_{i} / N_{i}$,

where ' $\mathrm{N}_{\mathrm{i}}$ ' denotes the total number of potential paths traversing at least once the landscape feature ' $i$ ' (leading or not to a deposition of fluorescent dye particles) and ' $n_{i}$ ' denotes the number of potential paths traversing at least once the landscape feature ' $i$ ' that actually led to a deposition of fluorescent dye particles at the destination point (Fig. 3). We obtained a value of permeability for each type of field margin and each type of polygon within the matrix, ranging from 0 (not traversed) to 1 (highly traversed by insect pollinators). The analysis was restricted to all sampling points encompassed within species dispersal distance to mimic the extent of pollinators' perception. 
(a)

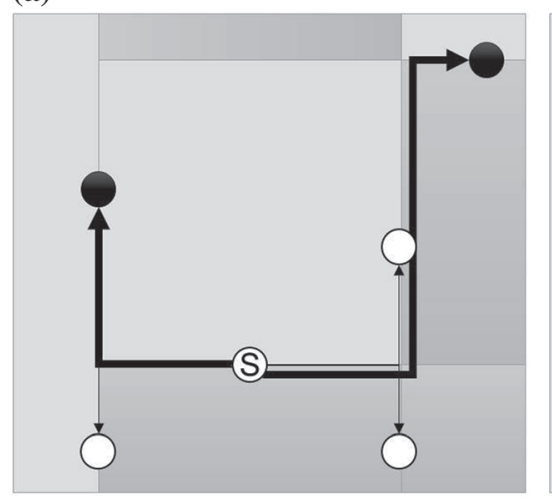

(b)

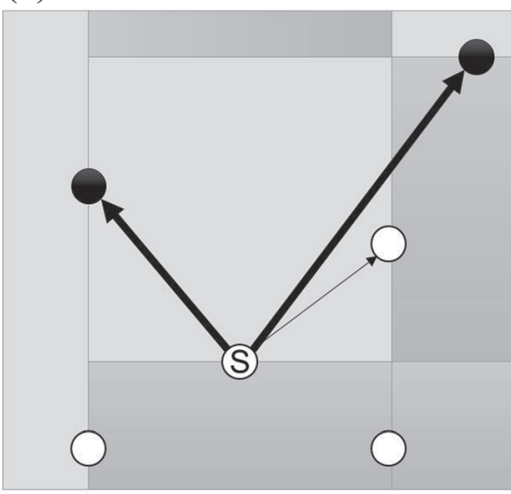

$=\mathbf{N}_{\mathbf{i}}$

$\rightarrow$ Potential path failing fluorescent dyes deposition event

(a) Via the field margins

Calculating permeability for 'unploughed field/ploughed field' field margins:

$\mathrm{N}_{\mathrm{i}}=5 ; \mathrm{n}_{\mathrm{i}}=2 ;$ Permeability $_{\mathrm{i}}=2 / 5$

\section{(b) Via the matrix}

\section{Calculating permeability for 'unploughed fields' polygons:}

$\mathrm{N}_{\mathrm{i}}=3 ; \mathrm{n}_{\mathrm{i}}=2 ;$ Permeability $_{\mathrm{i}}=2 / 3$

Fig. 3 Details on the elaboration of the permeability values assigned to each type of landscape features a via the field margins and $\mathbf{b}$ via the matrix. $n_{i}$ Sum of potential paths traversing a landscape feature ' $i$ ' and leading to a deposition of

Finally, to apply the least-cost algorithm with ArcGIS 10.2., we transformed the permeability maps into resistance maps that depict the ecological costs of landscape features imposed on dispersers (Baguette et al. 2012), following:

$$
\begin{aligned}
& \text { Resistance }\left(\text { landscape feature ' } i ’^{\prime}\right) \\
& =101-\left(100 \times \text { Permeability }_{i}\right)
\end{aligned}
$$

Theoretically resistance maps can range from 1 (lowest resistance for pollinators' movement) to 101 (the highest resistance thus impeding dispersers to move; See Electronic supplementary material).

Modelling functional connectivity

\section{Importance of field margins}

To examine whether pollinators' movement preferentially occurred along field margins or via the matrix, we computed two types of distances between the source and each 'Step-by-step' sampling points, following a straight-line model versus a field margins fluorescent dye particles at the destination point; $N_{i}$ total number of potential paths along which ' $i$ ' is encountered; Permeability the permeability of a landscape feature ' $i$ '

model, i.e. considering pollinators will not take shortcuts throughout the matrix.

In the context of the least-cost algorithm, we expressed these two extreme models according to the distances associated with the least-cost paths, i.e. minimal cumulative cost of moving to reach a target patch (Adriaensen et al. 2003). Hence, for the straightline model, we set all resistance values to 1 , identifying a uniform landscape. Contrastingly, for the field margins model, we allocated a resistance value of 1 to field margins (as well as to roads and paths that were not barriers to dispersal according to our field observations) and of 101 to any other landscape features. We obtained a matrix homogeneously impermeable to pollinators' movement. From these two resistance maps, we applied the 'Cost distance' tool (ArcGIS 10.2.) to assess the minimal cumulated cost-distance between the source (i.e. centre of the field margin receiving fluorescent dyes) and any destination (i.e. 'Step-by-step' sampling points). Then, we implemented both distances (straight-line and field margins) into the 'probability of dispersal' (Bunn et al. 2000; 
Urban and Keitt 2001), a classic negative exponential dispersal kernel (e.g. Hanski 1994) between the source ' $i$ ' and a destination point ' $j$ ' separated by a distance ' $d_{i j}$ ', following:

$p_{i j}=\exp \left(-d_{i j} \times \theta\right)$

' $\theta$ ' reflects species dispersal ability and is parameterised considering that a probability of dispersal of 0.01 is achieved for the maximum dispersal distance observed in situ. Hence, we converted observed maximum dispersal distances to meet the assumptions of the two tested dispersal patterns, and we obtained for C. sancta: $155 \mathrm{~m}$ (field margins) and $135 \mathrm{~m}$ (straight-line) while for E. serrata: $635 \mathrm{~m}$ (field margins) and $623 \mathrm{~m}$ (straight-line).

Finally, we confronted the proportion of inflorescences with fluorescent dyes observed in situ to the modelled probability of dispersal via generalised linear models (probit link). We used AICc values, AICc weights $\left(\omega_{\mathrm{i}}\right)$ and the evidence ratio in accordance with Burnham et al. (2011) to select the best model (straight-line versus field margins).

Influence of the surrounding matrix and field margins quality

To refine our understanding of pollinators' movement, we integrated the influence of the surrounding matrix and field margins quality, defined as the relative abundance of C. sancta or E. serrata, by comparing the performance of alternative models to our reference models. The reference models are the ones obtained from the straight-line and field margins distances. We derived each alternative model from our empirical resistance maps (see 2.4.). The straight-line with heterogeneity model refines the straight-line model by assuming that landscape heterogeneity may influence pollinators' movement. We combined resistance values of both field margins and other landscape features (values ranging from 1 to 101). The field margins with heterogeneity model refines the field margins model by presuming that pollinators follow field margins which differ in their permeability, depending on the surrounding matrix. Hence, we extracted resistance values for field margins only, ranging from 1 to 101 . The resistance of other landscape features was set to 101 (impermeable to dispersers). Finally, with the GIS procedure described in "Importance of Field Margins" section, we obtained two new effective distances $\left(\mathrm{d}_{\mathrm{ij}}\right)$ from the straight-line with heterogeneity and field margins with heterogeneity resistance maps, between pairs of source and destination points that were integrated into Eq. 3. Additionally, we made further refinements to test whether the quality of field margins influences the movement of pollinators by attracting them into areas of higher floral resources. To do so, we weighted $p_{i j}$, calculated for both the reference and alternative models, by the relative abundance of $C$. sancta or E. serrata at the destination:

$p_{i j} *=a_{j} \times p_{i j}=a_{j} \times \exp \left(-d_{i j} \times \theta\right)$,

where ' $a_{j}$ ' denotes plants abundance for a given destination point divided by the highest level of abundance (=3), thus standardizing $p_{i j}$ * from 0 to 1 . Ultimately, we performed generalised linear models linking the proportion of inflorescences with fluorescent dyes with $\mathrm{p}_{\mathrm{ij}}$ and $\mathrm{p}_{\mathrm{ij}}{ }^{*}$, to compare the statistical relevance of alternative models to reference models.

All statistical analysis previously mentioned were implemented in R 3.1.2. (R Development Core Team 2013).

\section{Results}

Species response to landscape structure

Overall, C. sancta and E. serrata occur in respectively 41.4 and $34.4 \%$ of the $293 \mathrm{~km}$ field margins network. The model selection highlights that various landscape indices best predict the abundance pattern, depending on the spatial scale and the study species (Table 1). Regarding $C$. sancta at the $250 \mathrm{~m}$ scale, the two best models include the proportion of unploughed fields with or without the proportion of pastures and fallow lands. Given the very low $\triangle \mathrm{AICc}$, the weak evidence ratio $(=2.14)$ and the fact that the proportion of pastures and fallow lands is not significant $(\mathrm{P}>0.1)$, we keep the simplest as the best one (model B; explained deviance $=21.33 \%$ ). At the $500 \mathrm{~m}$ extent, the proportion of unploughed fields is also the variable best explaining the abundance of $C$. sancta (explained deviance $=11.05 \%$ ). This model was only 2.3 times more plausible than the null model.

Contrastingly, at $250 \mathrm{~m}$, the abundance of $E$. serrata is mainly explained by the density of field margins (explained deviance $=11.65 \%$ ) alone or in combination with landscape heterogeneity $(\mathrm{P}>0.1$; evidence ratio $=2$; Table 1 ), while at $500 \mathrm{~m}$, it is 
Table 1 Results from generalised linear models comparing the ability of landscape structure models to predict the abundance of Crepis sancta and Euphorbia serrata at the field border for two spatial scales (250/500 m)

\begin{tabular}{|c|c|c|c|c|c|c|c|c|c|}
\hline Species & $\begin{array}{l}\text { Scale } \\
(\mathrm{m})\end{array}$ & Rank & Model & $\mathrm{Np}$ & AICc & $\triangle \mathrm{AICc}$ & $\omega_{\mathrm{i}}$ & $\begin{array}{l}\text { Evidence } \\
\text { ratio }\end{array}$ & $\begin{array}{l}\text { Explained } \\
\text { deviance } \\
(\%)\end{array}$ \\
\hline \multirow{8}{*}{$\begin{array}{l}\text { Crepis } \\
\text { sancta }\end{array}$} & \multirow[t]{4}{*}{250} & A & $\mathrm{Ab} \sim \mathrm{P}(\mathrm{PFL})+\mathrm{P}($ unploughed fields $)$ & 3 & 62.96 & 0.00 & 0.47 & & 28.39 \\
\hline & & $\mathrm{B}$ & $\mathrm{Ab} \sim \mathrm{P}$ (unploughed fields) & 2 & 64.46 & 1.50 & 0.22 & 2.14 & 21.33 \\
\hline & & $\mathrm{C}$ & $\begin{array}{l}\mathrm{Ab} \sim \text { heterogeneity }+\mathrm{P}(\text { unploughed } \\
\text { fields })+ \text { density of field margins }+\mathrm{P}(\mathrm{PFL})\end{array}$ & 5 & 67.22 & 4.26 & 0.06 & 7.8 & 31.73 \\
\hline & & $\mathrm{D}$ & $\mathrm{Ab} \sim 1$ & 1 & 74.08 & 11.13 & 0.00 & & 0 \\
\hline & \multirow[t]{4}{*}{500} & A & $\mathrm{Ab} \sim \mathrm{P}$ (unploughed fields) & 2 & 55.32 & 0.00 & 0.32 & & 11.05 \\
\hline & & $\mathrm{B}$ & $\mathrm{Ab} \sim 1$ & 1 & 56.91 & 1.59 & 0.14 & 2.3 & 0 \\
\hline & & $\mathrm{C}$ & $\mathrm{Ab} \sim \mathrm{P}(\mathrm{PFL})+\mathrm{P}($ unploughed fields $)$ & 3 & 57.42 & 2.10 & 0.11 & 2.9 & 12.40 \\
\hline & & $\mathrm{D}$ & $\begin{array}{l}\mathrm{Ab} \sim \text { heterogeneity }+\mathrm{P}(\text { unploughed } \\
\text { fields })+ \text { density of field margins }+\mathrm{P}(\mathrm{PFL})\end{array}$ & 5 & 62.97 & 7.65 & 0.01 & 32 & 16.67 \\
\hline \multirow{9}{*}{$\begin{array}{l}\text { Euphorbia } \\
\text { serrata }\end{array}$} & \multirow[t]{5}{*}{250} & A & $\mathrm{Ab} \sim$ density of field margins & 2 & 75.64 & 0.00 & 0.38 & & 11.65 \\
\hline & & $\mathrm{B}$ & $\mathrm{Ab} \sim$ density of field margins + heterogeneity & 3 & 77.1 & 1.46 & 0.19 & 2 & 13.93 \\
\hline & & $\mathrm{C}$ & $\mathrm{Ab} \sim \mathrm{P}(\mathrm{PFL})+$ density of field margins & 3 & 77.68 & 2.04 & 0.14 & 2.7 & 13.03 \\
\hline & & $\mathrm{D}$ & $\mathrm{Ab} \sim 1$ & 1 & 80.14 & 4.50 & 0.04 & 9.5 & 0 \\
\hline & & $\mathrm{E}$ & $\begin{array}{l}\mathrm{Ab} \sim \text { heterogeneity }+\mathrm{P}(\text { unploughed } \\
\text { fields })+ \text { density of field margins }+\mathrm{P}(\mathrm{PFL})\end{array}$ & 5 & 82.53 & 6.89 & 0.01 & 38 & 14.40 \\
\hline & \multirow[t]{4}{*}{500} & A & $\mathrm{Ab} \sim \mathrm{P}(\mathrm{PFL})$ & 2 & 50.68 & 0.00 & 0.58 & & 19.45 \\
\hline & & B & $\mathrm{Ab} \sim \mathrm{P}(\mathrm{PFL})+$ density of field margins & 3 & 52.85 & 2.17 & 0.20 & 2.9 & 20.49 \\
\hline & & $\mathrm{C}$ & $\begin{array}{l}\mathrm{Ab} \sim \text { heterogeneity }+\mathrm{P}(\text { unploughed } \\
\text { fields })+ \text { density of field margins }+\mathrm{P}(\mathrm{PFL})\end{array}$ & 5 & 56.38 & 5.70 & 0.03 & 19.3 & 26.44 \\
\hline & & D & $\mathrm{Ab} \sim 1$ & 1 & 60.13 & 9.45 & 0.01 & 58 & 0 \\
\hline
\end{tabular}

Selection of the four to five best models at each spatial scale

$A b$ abundance, $P$ proportion, $P F L$ pastures and fallow lands, $N p$ : number of parameters, $\omega_{i}$ AICc weights

explained by the proportion of pastures and fallow lands (explained deviance $=19.45 \%$ ). The topranked model (model $\mathrm{A}$ ) was 9.5 and 58 times more plausible than the null model at the spatial scales of $250 \mathrm{~m}$ and $500 \mathrm{~m}$, respectively.

Inter-margin fluorescent dyes dispersal pattern and functional connectivity modelling

\section{Importance of field margins}

Experimental data reveal that for both species the proportion of inflorescences with fluorescent dyes rapidly decreases with the distance from the source field margin. Additionally, it follows well the negative exponential dispersal model (Eq. 3). The proportion of inflorescences with fluorescent dyes ranges from 0 to 0.96 for $E$. serrata, while varying from 0 to 0.36 for $C$. sancta (Fig. 4).
For C. sancta, the straight-line model (explained deviance $=86.7 \%$ ) performs better than the field margins model (Table 2; Fig. 4a and b) in explaining the proportion of inflorescences with fluorescent dyes. Regarding E. serrata, the field margins model (explained deviance $=37 \%$ ) exhibits the strongest correlation with the proportion of inflorescences with fluorescent dyes (Table 2; Fig. 4c and d). This model is around 50 times more plausible than the straightline model.

Influence of the surrounding matrix and field margins quality

For $C$. sancta, the pattern of fluorescent dyes dispersal strongly correlates with straight-line model (Table 2). Accounting for landscape heterogeneity or for the quality of field margins does not lead to significantly better predictions of the empirical data. The top- 
ranked model is around five times more plausible than the second-ranked model. Regarding E. serrata, effective distances via field margins coupled with field margins quality, are the best predictors of the pollen dispersal pattern (Table 2), though considering the quality of destination field margins only increased

\section{(a)}

Proportion of inflorescences with fluorescent dyes

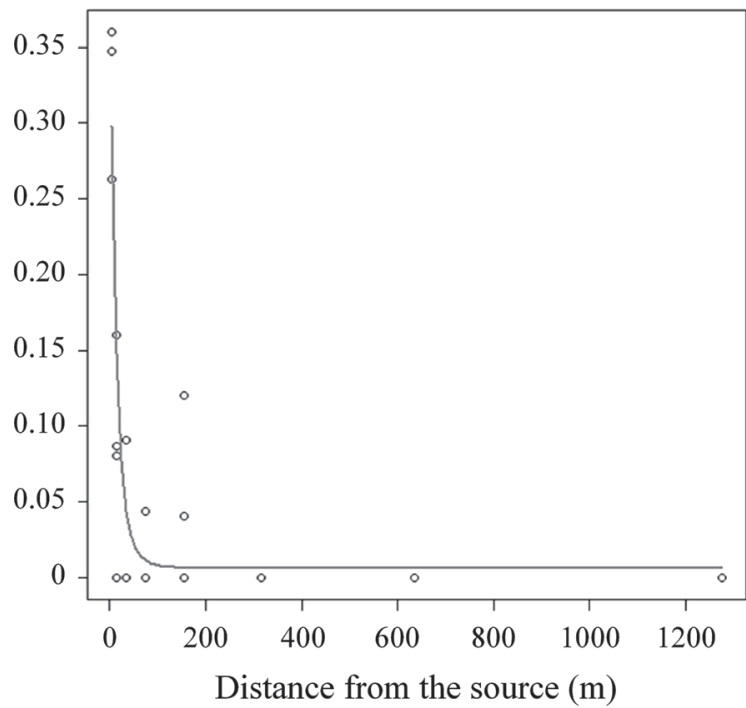

(c)

Proportion of inflorescences with fluorescent dyes

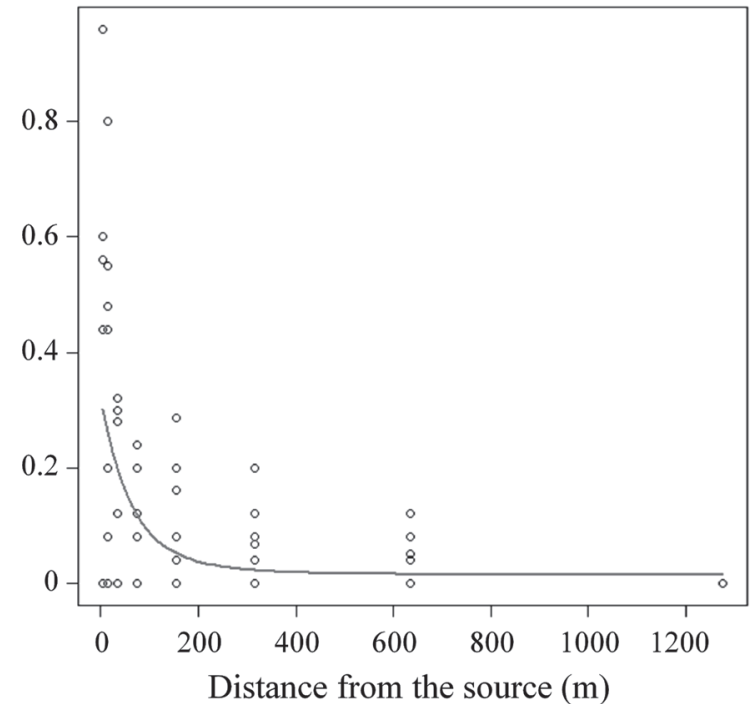

Fig. 4 Proportion of Crepis sancta and Euphorbia serrata inflorescences with fluorescent dye particles relative to the distance from the source per dispersal pattern. a Field margins model and b straight-line model for Crepis sancta; c Field the explained deviance by $2 \%$. Accounting more finely for landscape resistance (field margins with heterogeneity model) does not significantly improve the predictions. Overall, we detected better model fits for $C$. sancta (explained deviance $>80 \%$ ) than for $E$. serrata (ranging from 21.1 to $39 \%$ ).

\section{(b)}

Proportion of inflorescences with fluorescent dyes

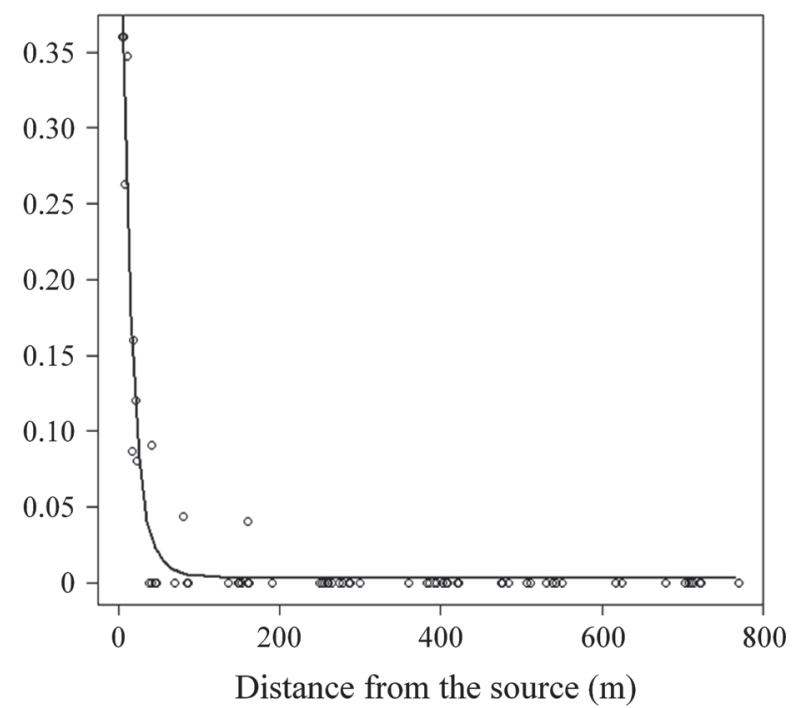

(d)

Proportion of inflorescences with fluorescent dyes

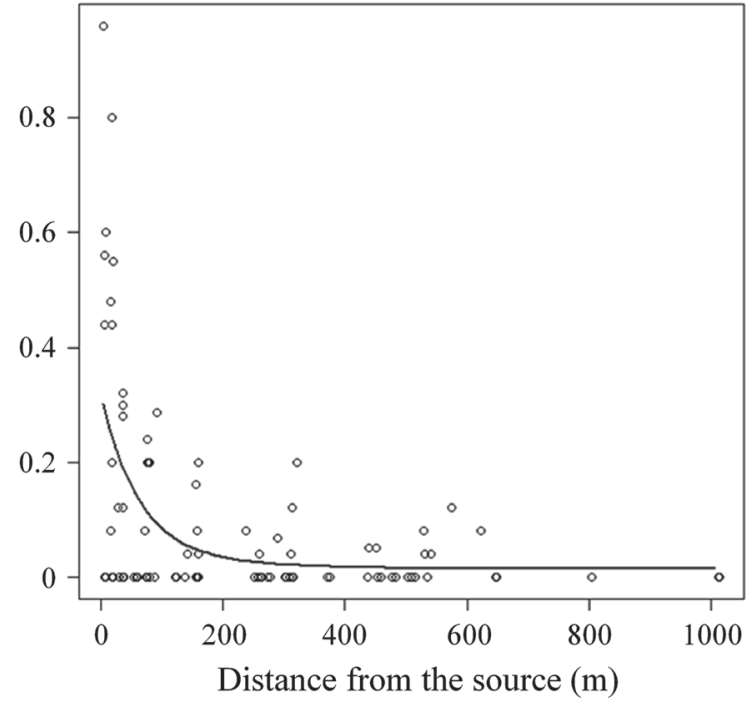

margins model and $\mathbf{d}$ straight-line model for Euphorbia serrata. The curves represent the distribution expected under the negative exponential dispersal kernel for the best-fitting parameters 
Table 2 Results from generalised linear models comparing the ability of functional connectivity models to predict the fluorescent dyes dispersal pattern

\begin{tabular}{|c|c|c|c|c|c|c|c|}
\hline & Species & Model & $\mathrm{AICc}$ & $\Delta \mathrm{AICc}$ & $\omega_{\mathrm{i}}$ & $\begin{array}{l}\text { Evidence } \\
\text { ratio }\end{array}$ & $\begin{array}{l}\text { Explained } \\
\text { deviance } \\
(\%)\end{array}$ \\
\hline \multirow[t]{6}{*}{ Field margins importance } & \multirow[t]{3}{*}{$\begin{array}{l}\text { Crepis } \\
\text { sancta }\end{array}$} & $\begin{array}{l}\mathrm{P}(\text { inflorescences with } \\
\text { dyes }) \sim \mathrm{p}_{\mathrm{ij}} \text { (straight-line) }\end{array}$ & 54.78 & 0.00 & 1.00 & & 86.7 \\
\hline & & $\begin{array}{l}\mathrm{P}(\text { inflorescences with } \\
\left.\text { dyes }) \sim \mathrm{p}_{\mathrm{ij}} \text { (field margins }\right)\end{array}$ & 70.14 & 15.36 & 0.00 & & 75.8 \\
\hline & & $\mathrm{P}($ inflorescences with dyes $) \sim 1$ & 175.17 & 120.39 & 0 & & 0 \\
\hline & \multirow[t]{3}{*}{$\begin{array}{l}\text { Euphorbia } \\
\text { serrata }\end{array}$} & $\begin{array}{l}\mathrm{P}(\text { inflorescences with } \\
\text { dyes }) \sim \mathrm{p}_{\mathrm{ij}} \text { (field margins) }\end{array}$ & 491.81 & 0.00 & 0.98 & & 37.0 \\
\hline & & $\begin{array}{l}\mathrm{P}(\text { inflorescences with } \\
\text { dyes }) \sim \mathrm{p}_{\mathrm{ij}}(\text { straight-line })\end{array}$ & 500.03 & 8.22 & 0.02 & 49 & 35.0 \\
\hline & & $\mathrm{P}($ inflorescences with dyes $) \sim 1$ & 711.57 & 219.76 & 0 & & 0 \\
\hline \multirow[t]{10}{*}{$\begin{array}{l}\text { Influence of the matrix and } \\
\text { the quality of field margins }\end{array}$} & \multirow[t]{5}{*}{$\begin{array}{l}\text { Crepis } \\
\quad \text { sancta }\end{array}$} & $\begin{array}{l}\mathrm{P}(\text { inflorescences with } \\
\text { dyes }) \sim \mathrm{p}_{\mathrm{ij}}(\text { straight-line })\end{array}$ & 54.78 & 0.00 & 0.78 & & 86.7 \\
\hline & & $\begin{array}{l}\mathrm{P}(\text { inflorescences with } \\
\quad \text { dyes }) \sim \mathrm{p}_{\mathrm{ij}}{ }^{*}(\text { straight-line })\end{array}$ & 57.84 & 3.06 & 0.17 & 4.6 & 84.5 \\
\hline & & $\begin{array}{l}\mathrm{P}(\text { inflorescences with } \\
\text { dyes }) \sim \mathrm{p}_{\mathrm{ij}} \text { (straight-line with } \\
\text { heterogeneity) }\end{array}$ & 60.95 & 6.17 & 0.04 & 19.5 & 82.3 \\
\hline & & $\begin{array}{l}\mathrm{P}(\text { inflorescences with } \\
\text { dyes }) \sim \mathrm{p}_{\mathrm{ij}}{ }^{*}(\text { straight-line with } \\
\text { heterogeneity })\end{array}$ & 63.28 & 8.50 & 0.01 & 78 & 80.6 \\
\hline & & $\mathrm{P}($ inflorescences with dyes $) \sim 1$ & 175.17 & 120.39 & 0 & & 0 \\
\hline & \multirow[t]{5}{*}{$\begin{array}{l}\text { Euphorbia } \\
\text { serrata }\end{array}$} & $\begin{array}{l}\mathrm{P}(\text { inflorescences with } \\
\text { dyes }) \sim \mathrm{p}_{\mathrm{ij}}^{*}(\text { field margins })\end{array}$ & 480.42 & 0.00 & 1.00 & & 39.0 \\
\hline & & $\begin{array}{l}\mathrm{P}(\text { inflorescences with } \\
\text { dyes }) \sim \mathrm{p}_{\mathrm{ij}}(\text { field margins })\end{array}$ & 491.81 & 11.4 & 0.00 & & 37.0 \\
\hline & & $\begin{array}{l}\mathrm{P}(\text { inflorescences with } \\
\text { dyes }) \sim \mathrm{p}_{\mathrm{ij}}(\text { field margins with } \\
\text { heterogeneity) }\end{array}$ & 540.67 & 60.26 & 0.00 & & 27.4 \\
\hline & & $\begin{array}{l}\mathrm{P}(\text { inflorescences with } \\
\text { dyes }) \sim \mathrm{p}_{\mathrm{ij}} *(\text { field margins with } \\
\text { heterogeneity) }\end{array}$ & 580.05 & 99.63 & 0.00 & & 21.1 \\
\hline & & $\mathrm{P}$ (inflorescences with dyes) $\sim 1$ & 711.57 & 219.76 & 0 & & 0 \\
\hline
\end{tabular}

$P$ proportion, $p_{i j}$ probability of dispersal between a source ' $i$ ' and a destination point ' $j$ ', $p_{i j}$ ' probability of dispersal weighted by field margins quality, $\omega_{i}$ AICc weights

\section{Discussion}

Plant species abundance and dispersal patterns across a peri-urban agricultural landscape

\section{Plant species abundance modulated by landscape} structure

Following our first objective, little evidence was found of the influence of landscape structure on species abundance and we found a high degree of uncertainty regarding the best models. However, our results confirm three main trends that have already been largely discussed for other types of organisms. We found that the relation between abundance and landscape structure is somewhat depending on both (i) the spatial scale and (ii) the species as previously demonstrated on animal species (Brennan and Schnell 2005; Barbaro et al. 2007). While the abundance of $C$. sancta was moderately determined by the proportion of unploughed fields (250 and $500 \mathrm{~m}$ spatial scales) the abundance of E. serrata slightly benefited from the 
density of field margins $(250 \mathrm{~m})$ and the proportion of pastures and fallow lands $(500 \mathrm{~m})$. A possible explanation relates to species life-history traits. Indeed, perennial species (e.g. E. serrata) express a higher sensitivity to mechanical soil perturbations within fields (e.g. ploughing, which occurred in March and May for the ploughed and unploughed fields, respectively) than annual species, being thus restricted to less agriculturally disturbed habitats such as field margins (Saatkamp et al. 2007; Fried et al. 2009). Finally, our results emphasise that the heterogeneity of agroecosystems partly supports farmland species abundance within a fragmented peri-urban agricultural landscape (Benton et al. 2003; Vasseur et al. 2013). The heterogeneity of agro-ecosystems may indeed act as a lever of action to ensure an appropriate landscape management for plant species occurring in field margins. Crepis sancta responds to crop heterogeneity (no monoculture cover; e.g. unploughed fields) while E. serrata responds to between-fields heterogeneity (noncropped habitats; e.g. field margins, fallow lands). Landscape heterogeneity sensu Burel and Baudry (1999) did not affect species abundance. Indeed, similar profiles of heterogeneity encountered in randomly sampled buffers centred on field margins, led to less strength to identify significant statistical trends for C. sancta and E. serrata.

\section{Influence of field margins and matrix heterogeneity on species dispersal}

In view of our second and third objectives, our results give three main elements of response: (i) dispersal ability differs between $C$. sancta and E. serrata, (ii) the preferred pattern of pollen dispersal depends on the study species and (iii) field margins may facilitate pollinators' movement.

Regardless of the study species, our findings suggest that strongly-linked field margins (regarding functional connectivity) exhibit a high proportion of inflorescences with fluorescent dye particles. However, both species displayed contrasted maximum dispersal distances (C. sancta: $133 \mathrm{~m}$ and E. serrata: $635 \mathrm{~m}$ ), thus emphasising the importance of a speciesspecific assessment of connectivity (Tischendorf and Fahrig 2000). We may impute such a difference to the contrasting composition of pollinators guilds. Indeed, among the 13 species of the $C$. sancta guild (C. Guiller, pers. obs.), Apoidea significantly contribute to pollination. Bees foraging efficiency and behaviour proceed from distances between nesting sites and foraging habitats coupled with resources availability (Steffan-Dewenter and Kuhn 2003; Williams and Kremen 2007; Zurbuchen et al. 2010), hence they may preferentially visit profitable areas nearby their hives. If they do adopt this behaviour here, the lower dispersal distance of fluorescent dye particles is easily conceivable, considering the mass-flowering resources of $C$. sancta provided by unploughed fields adjacent to the source. Conversely, we described a more diversified guild for E. serrata (31 species; C. Guiller, pers. obs.), among which sawflies (e.g. Athalia sp., Macrophya sp., Tenthredo sp.) are known to be active dispersers with extended foraging areas (Nagasaka 1992; Liston et al. 2012).

Interestingly, our findings on functional connectivity indicate that $C$. sancta and E. serrata pollinators tend to use, on average, contrasted dispersal pathways. For C. sancta, analyses revealed a superior performance of the straight-line distance via landscape. Pollinators equally traversed field margins and the surrounding matrix. Moreover, dispersers were not specifically attracted by field margins with higher floral resource. Indeed, a particularly attractive resource of $C$. sancta provided by unploughed fields was available in the immediate vicinity of the source, within insect pollinators dispersal abilities. Hence, we can reasonably assume that this extensive floral resource modulates pollinators' movement, rather than floral resources in spatially restricted habitats such as field margins. However, note that we did not consider floral resources provided by other plant species that could as well influence insect foraging patterns.

Finally, we indicated that aside from offering suitable habitats, field margins may be valuable for species abundance and dispersal depending on species life-history traits in accordance with the findings of Van Geert et al. (2010) and Cranmer et al. (2012) on other agricultural linear elements.

Challenges of functional connectivity modelling for pollinated plants

Inconsistently with the dominant literature reporting that the matrix modulates connectivity between suitable habitats (e.g. Speckled wood butterfly (Pararge aegeria), Chardon et al. 2003; Red squirrel (Sciurus 
vulgaris), Verbeylen et al. 2003; Natterjack toad (Bufo calamita), Stevens et al. 2006), we found little support for the least-cost algorithm and the concept of matrix heterogeneity regarding the pollen dispersal patterns of our two plant species. Ecological costs classically outperform the straight-line distance when modelling species functional connectivity because they integrate dispersers' perception of landscape structure (Chardon et al. 2003). Here, while one of our species (E. serrata) was better predicted by the field margins model, thus confirming the relevance of the least-cost algorithm, the other one ( $C$. sancta) led to better predictions of the pollen pattern by straight-line distances. We may explain the latter pattern by three different reasons. (i) Given the low-contrast landscape contexts in the vicinity of the source points (low ratios of resistance values between adjacent landscape features) and the rapid distance decay of flower visitation (limited dispersal unlike usual animal dispersal distance; e.g. Stevens et al. 2006), we found similar performances of statistical models accounting for the heterogeneous matrix. (ii) C. sancta occurs in unploughed fields, which may lead pollinators to make intermediate stops between our sampling points. Additionally, it is pollinated by a generalist insect, Apis mellifera that may be attracted to a broader range of floral resources and thus be less affected by the apparent landscape heterogeneity, consistently with the findings of Foley and Holland (2010) on generalist flying beetles, known to travel straight between resources. (iii) Finally, the subtle contrasts pointed out between the alternative models integrating the heterogeneity of the matrix, and the reference models may proceed from the difficulty that we encountered in inferring the resistance values for each landscape feature. Indeed, inferring landscape resistance is a key stage for functional connectivity modelling, which classically involves expert opinions (Zeller et al. 2012) because tracking dispersers poses severe logistical challenges despite delivering accurate information about how organisms perceive landscape structure (Calabrese and Fagan 2004; Bélisle 2005). Here, it would have required a specific experimental design targeted on pollinator behaviour to accurately assign landscape permeability (e.g. Bélisle 2005; Hadley and Betts 2011; Bergerot et al. 2013). Although ecological costs allocated here did not derive from a subjective expertbased approach, our permeability elaboration may not be optimal to model pollen dispersal, and adds to our range of permeability that was potentially not contrasted enough thus affecting the performance of the least-cost algorithm, as suggested by Rayfield et al. (2010) and Koen et al. (2012). Given the low-fits and statistical uncertainties, we should interpret our results with care and we do not preclude the potentiality that our landscape resistance could be improved.

\section{Implication for land-managers facing changes}

in the agricultural practices within agroecosystems

Within the South of the Luberon Regional Natural Park, Meyer-Vale (2012) reports the existence of increasing agricultural pressures that aim at improving yields and facilitating the accessibility to the small sized fields $(80 \times 50 \mathrm{~m}$ on average in the study site $)$. It means that arable fields may be grouped (MeyerVale 2012) and we can reasonably expect that intensive farming practices will be operated to meet higher yields thus impeding the development of flowering resources within arable fields (e.g. reluctance to widely let permanent inter-row vegetation cover or even reluctance to delayed ploughing due to competition for water resources in vineyards under Mediterranean climate that would affect yields; CETE 2013). Conversely, agricultural policies in the Luberon Regional Natural Park aim at maintaining natural and semi-natural habitats (Meyer-Vale 2012). From the preceding, and based on our results that underlined a positive relationship between the abundance of $C$. sancta and the proportion of unploughed fields, we expect that landscape disturbances may counteract the occurrence of $C$. sancta. On the other hand, E. serrata would be maintained within the network of field margins as its abundance mainly relates to the proportion of field margins. Our results overall suggest that the landscape structure affects both common plant species abundance and their pollination patterns. These elements are known to be the key components of robust plant-pollinator interactions and the warrant of their stability in the long term (Ghazoul 2005; Hadley and Betts 2011). Here, the occurrence of E. serrata into field margins, its extended dispersal distance (ability to rescue and recolonize distant habitats; Henle et al. 2004) coupled with its more diverse guild of pollinators likely to help maintaining its pollination in the long-term (e.g. Kremen et al. 2002) would thus enable pollen- 
mediated gene flow under landscape disturbance such as intensive farming, as opposed to C. sancta (low dispersal ability and less diverse guild of pollinators to which would add the decline in the amount of suitable habitats caused by potential changes in farming practices). Although common plant species such as $C$. sancta and E. serrata are not currently threatened, they may be distinctly affected by future landscape disturbances given their life-history traits and how landscape structure modulates their contemporary abundance and dispersal patterns, and similarly for the functional groups they represent. Hence, our results have some implications for the planning of biodiversity management in agro-ecosystems. Indeed, our framework is a useful tool to identify which landscape features act as barriers or corridors for plant species dispersal. Based on species responses, we may formulate a few recommendations to enhance plant species abundance within field margins (e.g. delay ploughing in perennial fields, maintain or restore field margins for $C$. sancta and E. serrata, respectively) and to offer multiple dispersal routes for pollinators (e.g. adapt mowing in the field margins to the phenology of E. serrata, enhance floral resources within pollinators foraging areas, for both species).

\section{Conclusion}

In this study, we proposed to combine field observations, experimentations and a modelling framework for two plant species representing different functional strategies in the floral assemblages of Mediterranean agro-ecosystems. With such an approach we have shown how both abundance and dispersal patterns were contrasted between two plant species representing distinct functional groups in plant assemblages that are infeoded to field margins within low-intensity agro-ecosystems. We emphasised that landscape structure and particular landscape features, such as field margins, may play an essential role on these patterns as they may either offer suitable habitat and/or facilitate species dynamics (abundance and dispersal). Consequently, our results could help formulating management recommendations to optimise landscape connectivity via a dual action on the matrix and field margins and cope with the expected effects of agricultural intensification on the conservation of a subset of biodiversity which is not rare but still constrained to specific semi-natural habitats. Finally, our framework could help bridge the gap between criticised agri-environment schemes aiming at limiting the impacts of agricultural intensification, and wide environmental policies sustaining landscape connectivity ('green-veining' policy).

Acknowledgments This study was funded by the Luberon Natural Regional Park (Ref. PNRL1803/OA14AVHRXT). We would like to thank Arne Saatkamp for useful comments on the manuscript and Michael Paul for greatly improving the English of this paper (Ref. 4500180790).

\section{Compliance with ethical standards}

Conflict of Interest The authors declare that they have no conflict of interest.

\section{References}

Adriaensen F, Chardon JP, De Blust G, Swinnen E, Villalba S, Gulinck H, Matthysen E (2003) The application of 'leastcost' modelling as a functional landscape model. Landsc Urban Plan 64:233-247

Adriaensen F, Githiru M, Mwang'ombe J, Matthysen E, Lens L (2007) Restoration and increase of connectivity among fragmented forest patches in the Taita Hills, South-East Kenya. CEPF Project 1095347968, University of Ghent, Ghent, Belgium

Baguette M, Blanchet S, Legrand D, Stevens VM, Turlure C (2012) Individual dispersal, landscape connectivity and ecological networks. Biol Rev Cambr Philos Soc $88: 310-326$

Baiges JC, Blanché C (1991) Morphologie des graines des espèces ibéro-baléariques du genre Euphorbia L. (Euphorbiaceae) II-Subgen. Esula Pers. I. Bull Soc Bot Fr 138(4-5):321-327. doi:10.1080/01811797.1991.10824934

Barbaro L, Rossi JP, Vetillard F, Nezan J, Jactel H (2007) The spatial distribution of birds and carabid beetles in pine plantation forests: the role of landscape composition and structure. J Biogeogr 34:652-664

Bélisle M (2005) Measuring landscape connectivity: the challenge of behavioral landscape ecology. Ecology 86:1988-1995

Benton TG, Vickery JA, Wilson JD (2003) Farmland biodiversity: is habitat heterogeneity the key? Trends Ecol Evol 18:182-188

Bergerot B, Tournant P, Moussus JP, Stevens VM, Julliard R, Baguette M, Foltête JC (2013) Coupling inter-patch movement models and landscape graph to assess functional connectivity. Popul Ecol 55:193-203

Biau O, Chauvot N (2014) 2007-2012: la croissance démographique ralentit. Insee Flash Provence Alpes Côte d'Azur 9:1-2

Boussard H, Baudry J (2014) Chloe212: a software for landscape pattern analysis. http://www.rennes.inra.fr/sad/ Outils-Produits/Outils-informatiques/Chloe 
Brennan TS, Schnell GD (2005) Relationship between bird abundances and landscape characteristics: the influence of scale. Environ Monit Assess 105:209-228

Bunn AG, Urban DL, Keitt TH (2000) Landscape connectivity: a conservation application of graph theory. J Environ Manag 59:265-278

Burel F, Baudry J (1999) Ecologie du paysage. Concepts, méthodes et applications. Tec \& Doc Lavoisier, Paris

Burnham K, Anderson DR, Huyvaert KP (2011) AIC model selection and multimodel inference in behavioral ecology: some background, observations, and comparisons. Behav Ecol Sociobiol 65:23-35

Calabrese JM, Fagan WF (2004) A comparison shoppers' guide to connectivity metrics: trading off between data requirements and information content. Front Ecol Environ 2:529-536

CETE (2013) Continuités écologiques en milieu agricoles. Connaissances, expériences et éléments méthodologiques pour l'appui à la mise en œuvre. Zoom sur la région Provence Alpes Côtes d'Azur

Chardon JP, Adriaensen F, Matthysen E (2003) Incorporating landscape elements into a connectivity measure: a case study for the Speckled wood butterfly (Pararge aegeria L.). Landscape Ecol 18:561-573

Cranmer L, McCollin D, Ollerton J (2012) Landscape structure influences pollinator movements and directly affects plant reproductive success. Oikos 121:562-568

ESRI (2013) ArcGIS desktop: release 10. Environmental Systems Research Institute, Redlands

Etherington TR, Perry GLW, Cowan PE, Clout MN (2014) Quantifying the direct transfer costs of common brushtail possum dispersal using least-cost modelling: a combined cost-surface and accumulated-cost dispersal kernel approach. PLoS ONE 9(2):e88293

Ethier K, Fahrig L (2011) Positive effects of forest fragmentation, independent of forest amount, on bat abundance in eastern Ontario, Canada. Landscape Ecol 26:865-876

Fahrig L (2003) Effects of habitat fragmentation on biodiversity. Ann Rev Ecol Evol Syst 34:487-515

Ferreras P (2001) Landscape structure and asymmetrical interpatch connectivity in a metapopulation of the endangered Iberian lynx. Biol Conserv 100:125-136

Foley CJ, Holland JD (2010) Do flying beetles perceive humandominated landscapes as complex mosaics or binary patterns? Landsc Online 16:1-18

Fried G, Petit S, Dessaint F, Reboud X (2009) Arable weed decline in Northern France: crop edges as refugia for weed conservation? Biol Conserv 142:238-243

Ghazoul J (2005) Pollen and seed dispersal among dispersed plants. Biol Rev 80:413-443

Grashof-Bokdam C, van Langevelde F (2005) Green veining: landscape determinants of biodiversity in European agricultural landscapes. Landscape Ecol 20(4):417-439

Guende G, Olivier L (1993) Les mesures de sauvegarde et de gestion des plantes messicoles du Parc Naturel Régional du Luberon. In: Dalmas JP (ed) Faut-il sauver les mauvaises herbes?. Conservatoire de Gap-Charance, Gap, pp 179-188

Hadley AS, Betts MG (2011) The effects of landscape fragmentation on pollination dynamics: absence of evidence not evidence of absence. Biol Rev 87:526-544
Hanski I (1994) A practical model of metapopulation dynamics. J Anim Ecol 63:151-162

Henle K, Davies KF, Kleyer M, Margules C, Settele J (2004) Predictors of species sensitivity to fragmentation. Biodivers Conserv 13:207-251

Honnay O, Jacquemyn H (2007) Susceptibility of common and rare plant species to the genetic consequences of habitat fragmentation. Conserv Biol 21:823-831

Imbert E (2001) Historique de Crepis sancta (L.) Babc. dans la flore française. Soc Bot Fr 16:33-39

Klein AM, Vaissière BE, Cane JH, Steffan-Dewenter I, Cunningham SA, Kremen C, Tscharntke T (2007) Importance of pollinators in changing landscapes for world crops. Proc R Soc B 274:303-313

Koen E, Bowman J, Walpole AA (2012) The effect of cost surface parametrization on landscape resistance estimates. Mol Ecol Resour 12:686-696

Kremen C, Williams NM, Thorp RW (2002) Crop pollination from native bees at risk from agricultural intensification. Proc Natl Acad Sci USA 99:16812-16816

Le Roux X, Barbault R, Baudry J, Burel F, Doussan I, Garnier E, Herzog F, Lavorel S, Lifran R, Roger-Estrade J, Sarthou JP, Trommetter M (2008) Agriculture et biodiversité. Valoriser les synergies. Expertise scientifique collective, synthèse du rapport. INRA, Paris

Leimu R, Mutikainen P, Koricheva J, Fischer M (2006) How general are positive relationships between plant population size, fitness and genetic variation? J Ecol 94:942-952

Liston AD, Knight GT, Heibo E, Bland KP, Barstad TE, Blank SM, Boevé JL, Fiedler C, Grearson KJ, Halstead A, Jacobs HJ, Jansen E, Lønnve O, Prous M, Robinson J, Taeger A (2012) On Scottish sawflies, with results of the 14th International Sawfly Workshop, in the southern Highlands, 2010. Beitr Entomol 62:1-68

Marshall EJP, Moonen AC (2002) Field margins in northern Europe: their functions and interactions with agriculture. Agric Ecosyst Environ 89:5-21

McGarigal K, Cushman SA, Ene E (2012) FRAGSTATS v4: spatial pattern analysis program for categorical and continuous maps. Computer software program produced by the authors at the University of Massachusetts, Amherst. http:// www.umass.edu/landeco/research/fragstats/fragstats.html

Meyer-Vale A (2012) Etude relative au foncier agricole en Sud Luberon. Pôle Territoire, Eau, Environnement, Chambre d'agriculture Vaucluse, France

Nagasaka K (1992) Movement patterns of three Athalia sawflies in relation to the spatio-temporal distributions of their habitats. Res Popul Ecol 34:1-14

Petit R, Duminil J, Fineschi S, Hampe A, Salvini D, Vendramin G (2005) Comparative organization of chloroplast, mitochondrial and nuclear diversity in plant populations. Mol Ecol 14:689-701

R Development Core Team (2013) R: a language and environment for statistical computing. R Foundation for Statistical Computing, Vienna

Rayfield B, Fortin MJ, Fall A (2010) The sensitivity of least-cost habitat graphs to relative cost surface values. Landscape Ecol 25:519-532

Saatkamp A, Dutoit T, Roche P (2007) La flore du vignoble du pays d'Aigues: d'un espace méconnu à la biologie de ses espèces. Courr Sci Parc Nat Reg Luberon 8:56-76 
Steffan-Dewenter I, Kuhn A (2003) Honeybee foraging in differentially structured landscapes. Proc R Soc Lond B 270:569-575

Stevens VM, Leboulengé E, Wesselingh RA, Baguette M (2006) Quantifying functional connectivity: experimental assessment of boundary permeability for the natterjack toad (Bufo calamita). Oecologia 150:161-171

Stevenson CD, Ferryman M, Nevin OT, Ramsey AD, Bailey S, Watts K (2013) Using GPS telemetry to validate least-cost modeling of gray squirrel (Sciurus carolinensis) movement within a fragmented landscape. Ecol Evol 3(7):2350-2361

Sutcliffe OL, Bakkestuen V, Fry G, Stabbetorp OE (2003) Modelling the benefits of farmland restoration: methodology and application to butterfly movement. Landsc Urban Plan 63:15-31

Taylor PD, Fahrig L, Henein K, Merriam G (1993) Connectivity is a vital element of landscape structure. Oikos 68:571-573

Tewksbury JJ, Levey DJ, Haddad NM, Sargent S, Orrock JL, Weldon A, Danielson BJ, Brinkerhoff J, Damschen EI, Townsend P (2002) Corridors affect plants, animals, and their interactions in fragmented landscapes. PNAS 99:12923-12926

Tischendorf L, Fahrig L (2000) On the usage and measurement of landscape connectivity. Oikos 90:7-19

Townsend PA, Levey DJ (2005) An experimental test of whether habitat corridors affect pollen transfer. Ecology 86:466-475

Tscharntke T, Rand TA, Bianchi FJJA (2005) The landscape context of trophic interactions: insect spillover across the crop-noncrop interface. Ann Zool Fenn 42(4):421-432
Urban D, Keitt T (2001) Landscape connectivity: a graph-theoretic perspective. Ecology 82:1205-1218

Van Geert A, Van Rossum F, Triest L (2010) Do linear landscape elements in farmland act as biological corridors for pollen dispersal? J Ecol 98:178-187

Vasseur C, Joannon A, Aviron S, Burel F, Meynard JM, Baudry J (2013) The cropping systems mosaic: how does the hidden heterogeneity of agricultural landscapes drive arthropod populations? Agric Ecosyst Environ 166:3-14

Verbeylen G, Bruyn LD, Adriaensen F, Matthysen E (2003) Does matrix resistance influence Red squirrel (Sciurus vulgaris L. 1758) distribution in an urban landscape? Landscape Ecol 18:791-805

Williams NM, Kremen C (2007) Resource distributions among habitats determine solitary bee offspring production in a mosaic landscape. Ecol Appl 17:910-921

Young A, Boyle T, Brown T (1996) The population genetic consequences of habitat fragmentation for plants. Trends Ecol Evol 11:413-418

Zeller KA, McGarigal K, Whiteley AR (2012) Estimating landscape resistance to movement: a review. Landscape Ecol 27:777-797

Zurbuchen A, Cheesman S, Klaiber J, Müller A, Hein S, Dorn S (2010) Long foraging distances impose high costs on offspring production in solitary bees. J Anim Ecol 79:674-681 